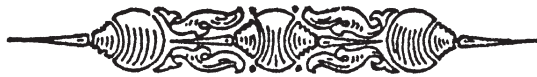

\title{
BOOTS FOR ACHILLES: PROGESTERONE'S REDUCTION OF CHOLESTEROL IS A SECOND-ORDER ADAPTATION
}

\author{
DORSA AMIR \\ Center for Behavior, Evolution, and Culture, Department of Anthropology, \\ University of California, Los Angeles \\ Los Angeles, California 90095-1553 USA \\ E-MAIL: DORSAAMIR@GMAIL.COM \\ DANiel M. T. Fessler \\ Center for Behavior, Evolution, and Culture, Department of Anthropology, \\ University of California, Los Angeles \\ Los Angeles, California 90095-1553 USA \\ E-MAIL:DFESSLER@ANTHRO.UCLA.EDU \\ KEYWORDS \\ progesterone, cholesterol, pregnancy, infection, evolutionary medicine
}

\section{ABSTRACT}

Progesterone and cholesterol are both vital to pregnancy. Among other functions, progesterone downregulates inflammatory responses, allowing for maternal immune tolerance of the fetal allograft. Cholesterol, a key component of cell membranes, is important in intracellular transport, cell signaling, nerve conduction, and metabolism. Despite the importance of each substance in pregnancy, one exercises an antagonistic effect on the other, as periods of peak progesterone correspond with reductions in cholesterol availability, a consequence of progesterone's negative effects on cholesterol biosynthesis. This arrangement is understandable in light of the threat posed by pathogens early in pregnancy. Progesterone-induced immunomodulation entails increased vulnerability to infection, an acute problem in the first trimester, when fetal development is highly susceptible to insult. Many pathogens rely on cholesterol for cell entry, egress, and replication. Progesterone's antagonistic effects on cholesterol thus partially compensate for the costs entailed by progesterone-induced immunomodulation. Among pathogens to which the host's vulnerability is increased by progesterone's effects, approximately $90 \%$ utilize cholesterol, and this is notably true of pathogens that pose a risk during pregnancy. In addition to having a number of possible clinical applications, our approach highlights the potential importance of second-order adaptations, themselves a consequence of the lack of teleology in evolutionary processes.

\section{INTRODUCTION}

$\mathrm{C}$

HOLESTEROL and progesterone each play a vital role in pregnancy. Intrigu- ingly, despite the importance of each, the latter exercises an antagonistic effect on the availability of the former. Here, we ar-

The Quarterly Review of Biology, June 2013, Vol. 88, No. 2

Copyright (C) 2013 by The University of Chicago Press. All rights reserved. 0033-5770/2013/8802-0002\$15.00 
gue that this puzzling arrangement reflects an evolved second-order adaptation, that is, an adaptation that addresses an adaptive challenge that is itself a consequence of the effects of another adaptation. Consider the following: it is well documented that cholesterol plays an important role in fetal development (Brizzi et al. 1999; Innis 2005; Woollett 2011). Although maternal triglycerides cannot directly cross the placental membrane, free fatty acids and ketones produced from those trigylcerides can cross the barrier, and are utilized by the fetus as both fuels and lipogenic substrates (Brizzi et al. 1999). It has been shown that when maternal plasma cholesterol is low $(<160$ $\mathrm{mg} / \mathrm{dL}$ ), birthweights are lower than normal, and there is a trend for microcephaly (Edison et al. 2007), suggesting that, although the fetus can also metabolize its own cholesterol, its capacity in this regard is limited and, hence, inadequate transfer of maternal cholesterol components negatively impacts fetal growth (Woolett 2011). Correspondingly, low intakes of specific fatty acids by the mother during gestation can result in decreased neural growth cones in the fetal brain, liver, and the placenta (Innis 2005). Paralleling the importance of cholesterol, the ovarian hormone progesterone, vital for the success of pregnancy, is unequivocally required in all mammals for maternal support of conceptus survival and development (Spencer and Bazer 2002). Progesterone is essential to several important events in the establishment of pregnancy, including ovum transport, endometrial cell proliferation, differentiation, decidualization, and the process of implantation. It is also vital for the maintenance of pregnancy, and a loss of progesterone is causally associated with miscarriage in early pregnancy (Macdonald 1989). It is therefore striking that a characteristic action of progesterone is its reduction of cholesterol. Progesterone has been shown to inhibit the esterification of cholesterol derived from low-density lipoproteins (LDLs), preventing its delivery to cellular enzymes (Metherall et al. 1996). Treatment of cholesterol with progesterone also causes the accumulation of sterol precursors, implying that cholesterol pro- duction pathways are disrupted (Lindenhall et al. 2001). Indeed, progesterone disrupts pathways involved in both cholesterol biosynthesis and the processing of LDLderived cholesterol (Lindenhall et al. 2001).

Why would a hormone that is intimately linked to successful pregnancy cause a reduction in the availability of a building block needed for fetal development? Although seemingly paradoxical, we suggest that this relationship constitutes a compromise solution to a problem that arises due to tradeoffs inherent in pregnancy. We review the respective roles of cholesterol and progesterone, describe the effects of progesterone on cholesterol availability, delineate the potential costs of this interaction, and then outline the benefits (in the form of reduced vulnerability to pathogens) that we hypothesize outweigh these costs.

\section{The Functions of Cholesterol And Its Role in Fetal Development}

Cholesterol, a lipid molecule with a characteristic four-ring steroid structure (Yoshida and Wada 2005), is vital to life. It is required as the structural component of mammalian cell membranes, helping to maintain proper permeability and fluidity (Yeagle 1985). Cholesterol also functions in intracellular transport, cell signaling (Maxfield and Tabas 2005), and nerve conduction (Saher et al. 2011). It is a fundamental mediator of metabolism through the propagation of signaling cascades and is essential to both the activation and propagation of hedgehog signaling (Woollett 2005). Additionally, cholesterol is the precursor for other necessary compounds, such as steroid hormones, bile acids, and vitamin D (Lecerf and de Lorgeril 2011), and is a significant component of lipid rafts in the plasma membrane, which serve as organizing centers for the assembly of signaling molecules (Rosenberger et al. 2000). Lipid rafts themselves play multiple functions, including polarized secretion, membrane transport, transcytosis across epithelial monolayers, and the generation of cell polarity (Rosenberger et al. 2000). Two types of lipoproteins are associated with cholesterol: high-density lipoproteins (HDLs) and low-density lipoproteins 
(LDLs). These function in the transport of cholesterol throughout the body. LDLs assist in the transport of cholesterol out of the liver, while HDLs act as acceptors of cholesterol and are believed to bring fat and cholesterol back to the liver (Grummer and Carroll 1988; Assmann and Gotto 2004). Regulation of synthesis, influx, and efflux keeps cellular cholesterol levels tightly controlled (Simons and Ikonen 2000).

Reflecting its many important functions in the body, cholesterol is a vital factor in development. Cholesterol's relationship to the Sonic hedgehog ( $\mathrm{Shh}$ ) group of proteins entails an essential role in embryonic development, as these proteins are required for morphogenesis; cholesterol modulates the function of the Shh group by binding a functional Shh fragment and thereby restricting the distribution and activity of the Shh signal on the cell membrane (Yoshida and Wada 2005). Correspondingly, cholesterol deficits during embryogenesis cause severe abnormalities (Kolejáková et al. 2010). To take one example, Smith-Lemli-Opitz syndrome, caused by an inherited defect in a specific enzyme in the cholesterol biosynthesis pathway, is characterized by abnormal development and poor function, especially in cognition (Salen et al. 1996). This is further supported by evidence showing correlations between statin use in pregnancy and fetal neurological damage, and impaired placental implantation and function (Kenis et al. 2005; Pollack et al. 2005; Lockshin 2010).

Consonant with the above, reflecting the substantial need for cholesterol during this time of rapid growth, fetal sterol synthesis rates are greater than those in other extrahepatic tissues (Woollett 2005). Importantly, however, although the fetus is able to synthesize its own cholesterol, because demand generally outstrips supply-such that maternal contribution is a limiting factor in fetal growth (Gluckman and Hanson 2004) — the fetus is dependent on maternal supply. Maternal cholesterol, in the form of lipoproteins, can enter into fetal circulation through uptake by the placenta and trophoblasts, via both receptor-mediated and receptor-independent transport (Wool- lett 2005). Correspondingly, studies consistently reveal an intimate relationship between maternal cholesterol levels and healthy fetal development (Brizzi et al. 1999; Innis 2005; Woollett 2011).

\section{Progesterone-Mediated Reductions in Cholesterol During Pregnancy, the Luteal Phase, and Menopause}

Early pregnancy is associated with a nadir in the mean value of serum cholesterol (Darmady and Postle 1982; Basaran 2009). Although cholesterol rises steadily through gestation, early in the first trimester there is an initial decrease in plasma lipids (Basaran 2009; Sep et al. 2011). Cholesterol levels eventually climb dramatically, but recovery from the initial decline is gradual, such that LDL levels at the end of the first trimester are often still within normal ranges (Brizzi et al. 1999); it is generally only by the beginning of the second trimester that cholesterol levels rise substantially above the pre-pregnancy baseline (Basaran 2009).

Importantly, the first-trimester decline in maternal cholesterol levels is not a consequence of utilization of maternal cholesterol by the conceptus, as total conceptus cell mass is small during the first-trimester cholesterol nadir and, moreover, the general pattern of cholesterol decline is not dependent on conception, as it also occurs during the luteal phase of menstrual cycles in which conception has not taken place. During the follicular phase of the menstrual cycle, total cholesterol levels peak (Kim and Kalkhof 1979; Ahumada Hemer et al. 1985; Jones et al. 1988), as do levels of LDL (Ahumada Hemer et al. 1985; Tikkanen et al. 1986). During the luteal phase, in which the endometrium is prepared for implantation, levels of both total serum cholesterol and triglycerides decline (De León et al. 1992). The luteal phase constitutes preparation for pregnancy and, correspondingly, pregnancy can be conceptualized as a continuation of changes present mid-luteally-declines in cholesterol thus occur in anticipation of, rather 
than as a consequence of, the presence and growth of a conceptus.

Progesterone is the principal candidate for the cause of the decline in cholesterol in the luteal phase and the early first trimester. Progesterone remains at a relatively low level throughout the follicular phase and during ovulation, but increases sharply during the luteal phase (De León et al. 1992). In the event of conception and implantation, progesterone continues to climb across the first trimester (Tay and Lenton 2002). Importantly, progesterone's cholesterol-reducing effects are well established. Studies have shown that progesterone inhibits the delivery of LDL-derived cholesterol to processing enzymes such as acetyl-Coenzyme A acetyltranferase (ACAT; Metherall et al. 1996). Progesterone inhibits the movement of LDL-derived cholesterol from lysosomes to the plasma membrane (Plemenitas et al. 1990), and the movement of cholesterol from the plasma membrane to the endoplasmic reticulum (Lange 1994). This movement of sterols from the plasma membrane to the endoplasmic reticulum is required for cholesterol biosynthesis (Metherall et al. 1996); thus, progesterone's impediment of LDL-derived cholesterol movement in turn impedes cholesterol biosynthesis. Consistent with the disruption of cholesterol production pathways, treating tissue with progesterone leads to an accumulation of sterol precursors (Lindenhall et al. 2001). At the organismic level, exogenous progesterone has been shown to reduce HDL cholesterol both when administered through progestin-only oral contraceptives (Wynn and Niththyananthan 1982) and when administered through hormone-replacement therapies in postmenopausal women (LamonFava et al. 2006).

Menopause is accompanied by a dramatic decline in progesterone levels and, consistent with the above portrait, across diverse populations, there is a corresponding increase in serum cholesterol during this period independent of the effects of age (Wu et al. 1990; Akahoshi et al. 1996; Matthews et al. 2009); correspondingly, surgical menopause has a similar effect (Akahoshi et al. 1996).
We are thus faced with the apparent contradiction that a hormone that is central to pregnancy causes a reduction in lipids that, being vital to cellular activity and cell division, are crucial to successful fetal development. To date, this question has not been explored. Several authors (Butte 2000; Toescu et al. 2002) have noted in passing that low cholesterol levels early in pregnancy correspond to an anabolic phase during which fat deposition is enhanced in anticipation of late pregnancy, when rapid fetal growth will require maternal catabolism. In this view, the initial reduction in gestational cholesterol levels is simply a side effect of the need to lay in energy stores for later. However, the ratio of cholesterol to triglycerides in fat cells is both constant and largely independent of cell size, indicating that both are likely deposited simultaneously in a fixed ratio (Kovanen et al. 1975) - a feature inconsistent with progesterone's disruption of cholesterol production. Hence, while there is conclusive evidence of a patterned shift from anabolism to catabolism across pregnancy, this pattern provides neither proximate nor ultimate explanations of the antagonistic effects of progesterone on cholesterol synthesis. Rather, we propose that the solution to this puzzle lies in the intersection of the effects of progesterone on the immune system and the role of cholesterol in infection.

\section{Progesterone-Induced IMMUNOMODULATION AND Compensatory Prophylaxis}

With half of its genome being paternally derived, from the perspective of the maternal immune system, the conceptus constitutes a genetically incompatible allograft. As a consequence, changes must occur in the maternal immune system in order to prevent maternal lymphocytes from attacking the conceptus (Szekeres-Bartho et al. 1983). Pregnancy is facilitated by a shift in the Th1/Th2 balance in maternal immune functioning, a move away from those inflammatory responses that pose the greatest danger to the invasive blastocyst and the subsequently semiparasitic embryo (reviewed in Fessler 2002; Doyle et al. 2007; 
Fleischman and Fessler 2011). Importantly, progesterone plays a central role in the immunomodulation necessary to tolerate the halfforeign conceptus (Siiteri et al. 1977). The downregulation of maternal inflammation is achieved through decreased levels of proinflammatory cytokines and natural killer cells. These changes are the downstream consequence of progesterone-induced blocking factor (PIBF), which shifts the maternal immunological balance toward anti-inflammatory signals (reviewed in Fessler 2001; see also Szekeres-Bartho et al. 1995; Doyle et al. 2007). Hence, progesterone is essential to pregnancy in part because it commands an immunomodulatory cascade that allows for tolerance of the half-foreign parasitic conceptus.

Maternal immune tolerance of the conceptus comes at a price as, by lowering host defenses, it increases the chances of infection (reviewed in Fessler 2001, 2002; Doyle et al. 2007). PIBF alters the cytokine secretion profile by increasing the production of Th2 cytokines and decreasing the production of Th1 cytokines (Faust et al. 1999). PIBF has also been shown to inhibit natural killer cell activity, through a blockade of degranulation (Faust et al. 1999). Both of these changes increase vulnerability to infection by lowering defenses in regard to both the detection and elimination of pathogens. Indeed, some pathogens may have evolved the ability to exploit this temporary weakening of host defenses; for example, progesterone not only increases the probability of infection by cytomegalovirus but, moreover, actually increases the pathogen's virulence (Chong and Mims 1984). Furthermore, increased maternal susceptibility to infection comes at a particularly dangerous time. Later in pregnancy the fetus eventually develops some autonomous defenses against pathogens, but these are absent early in development (Holt and Jones 2000). Moreover, the early first trimester is a critical period in fetal development, as organogenesis, concentrated during this phase, is a process that is especially vulnerable to insult (Arnold 1990) and, correspondingly, infection dur- ing the first trimester often can have drastic consequences (Wright 1966).

Progesterone's effects on the immune system clearly constitute an adaptation that serves to allow for gestation. Yet, this adaptation comes at the cost of increased susceptibility to infection during a particularly vulnerable period. Importantly, natural selection is not a teleological process-innovations that solve one problem can create another. Moreover, the liabilities entailed by one trait can, in turn, constitute a source of selective pressure leading to the evolution of new traits that mitigate the costs of these liabilities. Such second-order adaptations have been variously referred to as adaptive workarounds (Eastwick 2009) or the product of compensatory mutations (Maisnier-Patin and Andersson 2004). Of relevance to the matter at hand, recent evidence suggests that changes in other systems adaptively mitigate the vulnerability to pathogens entailed by progesterone's effects on the immune system. Specifically, alterations in behavior provide one avenue for such mitigation. The compensatory prophylaxis hypothesis holds that, because prophylactic behavior entails time, energy, attention, and opportunity costs, rather than remaining constant, prophylactic behavior should be enhanced during periods of increased susceptibility to infection, when the greater benefits obtained merit increased expenditures (Fessler and $\mathrm{Na}$ varrete 2003). Hence, because progesterone regulates a cascade of physiological events that result in increased vulnerability to infection, progesterone can be expected to also mediate increased behavioral prophylaxis (Fessler and Navarrete 2003). Consonant with this hypothesis, studies have shown increases in disgust sensitivity (a proximate mechanism subserving disease avoidance) during the vulnerable first trimester (Fessler et al. 2005). More specifically, disgust sensitivity, disease-avoidance behaviors, and related perceptions and attitudes all increase as a function of progesterone levels (Conway et al. 2007; Navarete et al. 2007; Fleischman and Fessler 2011; but see also Fessler and Navarrete 2003). Likewise, preferences for healthy over un- 
healthy faces (a cue of disease risk) are elevated during periods of elevated progesterone (Jones et al. 2005). Although compensatory prophylaxis is behavioral, we believe that a similar logic explains the effects of progesterone on cholesterol, as the latter plays a central role in infection.

\section{Cholesterol And Infection}

Critically, cholesterol plays a key role in infection. Lipid rafts are sites of entry and exit for a wide variety of viruses (Medigeshi et al. 2008). Lipid rafts can be exploited by pathogens in a number of ways. Some viruses, such as human immunodeficiency virus type 1 , coxsackievirus, simian virus 40 , and severe acute respiratory syndrome coronavirus, depend on lipid rafts for binding to and entry into the host cell; other viruses, such as rotavirus, Newcastle disease virus, influenza virus, Ebola virus, and Marburg virus, utilize raft-mediated pathways for assembly and egress (Chazal and Gerlier 2003; Mañes et al. 2003; Ono and Freed 2005; Pelkmans 2005).

A number of bacteria similarly exhibit cholesterol dependence, including Anaplasma phagocytophilum (Xiong et al. 2009), Escherichia coli (Goluszko and Nowicki 2005), Mycobacterium (Gatfield and Pieters 2000), Staphylococcus aureus (Liu et al. 2008), Salmonella (Hayward et al. 2005), and Shigella (Hayward et al. 2005), among others. Some, such as Mycobacterium tuberculosis, utilize cholesterol as a primary carbon source throughout the course of infection, such that degradation of this sterol is crucial for bacterial persistence (Miner et al. 2009). In other cases, in species such as Staphylococcus aureus that do not use cholesterol as a significant energy source (Shine et al. 1993), disruption of cholesterol biosynthesis nevertheless blocks bacterial virulence (Liu et al. 2008), as cholesterol is a key component of the cytoplasmic membrane (Yeagle 1985). Cholesterol dependency can be a distinguishing feature of the pathogenic adaptations of bacteria; indeed, an entire family of bacterial cytolysins is referred to as cholesterol-dependent cytolysins (CDCs) because they can only function effectively in the presence of host cholesterol. These pore-forming toxins are produced by more than 20 species from the genera Clostridium, Streptococcus, Listeria, Bacillus, and Arcanobacterium (Tweten 2005). Cholesterol-dependent cytolysins function both as simple hemolysins and as general cell-lytic agents that are crucial in bacterial infection (Tweten 2005). Conversely, bacterial sepsis causes decreases in the concentrations of total cholesterol, HDL, and apoproteins A and $\mathrm{B}$ of patients; the return of serum lipids to more normal concentrations parallels the recovery from sepsis (Alvarez and Ramos 1986). Although at present there is no consensus as to why this correlation exists, it may be that hypocholesterolemia in cases of sepsis is a component of defensive responses (Das et al. 2011).

Consonant with the thesis that the availability of cholesterol is a determinant of the ability of pathogens to proliferate, intriguing indications are emerging regarding a relationship between statin therapy, which decreases cholesterol, and a lower incidence of severe sepsis (Almog 2003). Statins display antimicrobial effects in many studies. Both in vivo and in vitro, statins reduce the intracellular growth of a subspecies of Salmonella enterica (Catron et al. 2004), while simvastatin has shown a significant antimicrobial effect against MSSA and, to a lesser extent, against MRSA (Jerwood and Cohen 2008).

Given that cholesterol plays a role in infectious disease, it is tempting to ask whether epidemiological studies reveal a link between cholesterol and infection. However, before reviewing this evidence, it is important to note that it is difficult to predict in advance how such correlations will play out. On the one hand, pathogens' dependence on cholesterol suggests that we might expect a straightforward positive correlation between the host's systemic cholesterol levels and morbidity and mortality due to infection. On the other hand, if the body is able to facultatively adjust cholesterol levels as a function of the individual's capacity to resist infection, then the opposite pattern may obtain, as individuals who are vulnerable to pathogens for reasons other than cholesterol availability may both exhibit lower cholesterol 
levels (reflecting an attempt to reduce vulnerability) and suffer higher rates of morbidity and mortality due to infection (reflecting the incomplete success of such efforts). Lastly, complicating the picture still further, it may be important to distinguish between different affordances of cholesterol from the perspective of the host. Although cholesterol facilitates infection and pathogen proliferation, once infection is established, cholesterol may sometimes benefit the host by reducing the destructive effects of endotoxins produced by some bacterial pathogens (Feingold et al. 1995; Ravnskov 2003). Accordingly, among individuals who are able to mount a robust immune response to infection, those having high cholesterol levels may suffer less pathogen-driven morbidity and mortality than those having low cholesterol levels.

Hospital studies reveal that low levels of HDL increase the probability of nosocomial infections (Delgado-Rodríguez et al. 1997; Canturk et al. 2002), and are predictors of in-hospital death and length of stay (Delgado-Rodríguez et al. 2002). These patterns are consistent with the thesis that cholesterol availability directly determines risk of infection, as HDL functions to transport excess cholesterol from the periphery to the liver for excretion into bile (Zhang et al. 2003), hence lower HDL levels equate to less reverse cholesterol transport and organ clearance, which, in turn, could conceivably lead to an increase in the amount of cholesterol available to pathogens elsewhere in the body. Conversely, however, outside of the hospital, among men, total cholesterol is inversely related to urinary tract, venereal, musculoskeletal, and all infections and, among women, to urinary tract, all genitourinary, septicaemia, bacteraemia, miscellaneous viral site unspecified, and all infections (Iribarren et al. 1998). Given the role of cholesterol in infection, the latter pattern strongly suggests that individual differences in cholesterol levels may reflect underlying differences in immunologic robustness, such that more vulnerable individuals maintain lower cholesterol levels in an incompletely successful effort to compensate for their vulnerability to pathogens.

A less direct route to exploring the relationship between cholesterol levels and infection is to consider cholesterol's effects on overall mortality. One difficulty in interpreting such patterns is the question of how to evaluate the respective effects of cholesterol on susceptibility to infection and cardiovascular disease. Although conventional wisdom holds that cholesterol contributes directly to cardiovascular disease, consonant with the view advanced here, Ewald (2008) presents a strong case that this correlation actually reflects the role of cholesterol in facilitating infection by pathogens such as Chlamydia that, in turn, damage blood vessels. Nevertheless, given that this remains a minority view, it is conservative to evaluate the contributions of cholesterol to mortality independent of deaths due to cardiovascular disease. Although a number of studies have sought to elucidate the relationship between cholesterol and noncardiovascular mortality, at present there is no consensus in the literature in this regard. Age may be an important factor. In adults over the age of 85, high total cholesterol concentrations are associated with longevity, seemingly from lower mortality due to cancer and infection (Weverling-Rijnsburger et al. 1997). A similar pattern of the protective effects of cholesterol has also been found among adults older than 55, who evince an inverse relationship between total cholesterol and several infectious diseases (Iribarren et al. 1998). Conversely, studies of younger adults reveal that the effect of total cholesterol on noncardiovascular mortality is neutral (Kronmal et al. 1993; Krumholz et al. 1994; Gould et al. 1995). Another study finds a trend of increased noncardiovascular mortality with decreased LDL, in both placebo and treatment groups (Razzolini et al. 2008). However, at each given LDL cholesterol level, noncardiovascular mortality is lower in patients treated with statins (Razzolini et al. 2008).

To summarize the above, at the cellular level, there is substantial evidence that cholesterol can play a key role in infection. At 
TABLE 1

Summary of survey of pathogens with regard to limiting and exacerbating cytokine responses, threat posed during pregnancy, and utilization of cholesterol

\begin{tabular}{|c|c|c|c|c|}
\hline Pathogen & $\begin{array}{c}\text { Limiting cytokine } \\
\text { response }\end{array}$ & $\begin{array}{c}\text { Exacerbating } \\
\text { cytokine response }\end{array}$ & $\begin{array}{c}\text { Threat during } \\
\text { pregnancy }\end{array}$ & $\begin{array}{c}\text { Cholesterol utility/ } \\
\text { dependence? }\end{array}$ \\
\hline Toxoplasma gondii & $\begin{array}{l}\text { Th1: IL-12, IL-6, TNF-alpha } \\
\quad(1,2) \\
\text { Th1: IL-1, IL-2, }\end{array}$ & Th2: IL-4 $(1,2)$ & Early pregnancy (3) & Yes $(4)$ \\
\hline $\begin{array}{l}\text { Escherichia coli } \\
\text { Brucella abortus, }\end{array}$ & IFN-gamma (5) & Th2: IL-10 (6) & Early pregnancy (7) & Yes (8) \\
\hline $\begin{array}{l}\text { Brucella } \\
\text { melitensis }\end{array}$ & $\begin{array}{l}\text { Th1: IL-12, IFN-gamma, } \\
\text { TNF-alpha (9) }\end{array}$ & Th2: IL-10, IL-4 (10) & Early pregnancy (83) & Yes (11) \\
\hline Shigella dysenteriae & Th1: IL-8, IL-2 (12) & & Early pregnancy (64) & Yes (13) \\
\hline $\begin{array}{l}\text { Campylobacter } \\
\text { jejuni }\end{array}$ & Th1: TNF-alpha, IL-8 (14) & & Early pregnancy (15) & Yes (16) \\
\hline Mycobacterium & Th1 (19) & Th2 (19) & & Yes (17) \\
\hline Coxsackievirus B & Th1: IFN-gamma (20) & Th2 (20) & Early pregnancy (54) & Yes $(35)$ \\
\hline Lassa virus & Th1: IL-6, IL-1beta (29) & & Third trimester (53) & Yes (18) \\
\hline Poliovirus & $\begin{array}{l}\text { Th1: IL-6, IL-8 (21), IFN } \\
\text { response (24) }\end{array}$ & & & Yes (23) \\
\hline CVB4 & Th1: IFN-gamma (25) & & & Yes (26) \\
\hline Helicobacter pylori & Th1: IFN-gamma (27) & Th2: IL-4 (28) & & Yes (36) \\
\hline $\begin{array}{l}\text { Leishmania } \\
\quad \text { donovani }\end{array}$ & $\begin{array}{l}\text { Th1: IFN-gamma, } \\
\text { IL-12 (30) }\end{array}$ & $\begin{array}{l}\text { Th2: IL-4, IL-5, IL-10 } \\
\quad(30)\end{array}$ & & Yes $(31)$ \\
\hline $\begin{array}{l}\text { Plasmodium } \\
\text { falciparum }\end{array}$ & $\begin{array}{l}\text { Th1: IFN-gamma (32), } \\
\text { TNF-alpha (33) }\end{array}$ & & & Yes (37) \\
\hline $\begin{array}{l}\text { Ehrlichia } \\
\quad \text { chaffeensis }\end{array}$ & Th1: IFN-gamma (34) & & & Yes (38) \\
\hline Salmonella enterica & $\begin{array}{l}\text { Th1: IFN-gamma, } \\
\text { TNF-alpha (39) }\end{array}$ & $\begin{array}{l}\text { Th2: IgG1/IgE } \\
(40,41)\end{array}$ & & Yes (42) \\
\hline $\begin{array}{l}\text { Semliki Forest } \\
\text { virus }\end{array}$ & Th1 (44) & $\begin{array}{l}\text { Anti-Thl: decreases } \\
\text { in IL-12, } \\
\text { IFN-gamma cause } \\
\text { increased and } \\
\text { prolonged } \\
\text { infection (43) }\end{array}$ & & Yes (45) \\
\hline $\begin{array}{l}\text { Epstein-Barr } \\
\text { virus }\end{array}$ & Th1: IFN-gamma (46) & Th2 (47) & & Yes (48) \\
\hline $\begin{array}{l}\text { Vesicular } \\
\text { stomatitis virus }\end{array}$ & Th1 (49) & & & Yes $(50)$ \\
\hline Dengue virus & Th1: IFN-gamma (51) & & & Yes (52) \\
\hline $\begin{array}{l}\text { Varicella } \\
\qquad \text { (Chickenpox) }\end{array}$ & $\begin{array}{l}\text { Th1: IL-6 (57), IFN-gamma, } \\
\text { IL-10, IL-12 (58) }\end{array}$ & & Early pregnancy (59) & Yes $(56)$ \\
\hline Parvovirus & Th1: IL-10, IFN-gamma (60) & & Early pregnancy (59) & Yes $(61)$ \\
\hline Rubella & Th1: IL-2, TNF-alpha (62) & & Early pregnancy (59) & $\begin{array}{l}\text { Yes. May depend on } \\
\text { macropinocytosis } \\
\text { for entry }(69), \\
\text { which requires } \\
\text { cholesterol }(70)\end{array}$ \\
\hline Influenza virus & Th1: IL-6 (63) & Th2: IL-4 (64) & Early pregnancy (66) & $\begin{array}{l}\text { Yes, decrease in } \\
\text { infectivity when } \\
\text { cholesterol depleted } \\
(65)\end{array}$ \\
\hline
\end{tabular}


TABLE 1

Continued

\begin{tabular}{|c|c|c|c|c|}
\hline Pathogen & $\begin{array}{l}\text { Limiting cytokine } \\
\text { response }\end{array}$ & $\begin{array}{c}\text { Exacerbating } \\
\text { cytokine response }\end{array}$ & $\begin{array}{c}\text { Threat during } \\
\text { pregnancy }\end{array}$ & $\begin{array}{c}\text { Cholesterol utility/ } \\
\text { dependence? }\end{array}$ \\
\hline \multicolumn{5}{|l|}{ Seasonal } \\
\hline Influenza A & Mixed response: TNF-alpha, & & & \\
\hline $\begin{array}{l}\text { (H1N1) } \\
\text { Adenoviruses }\end{array}$ & $\begin{array}{c}\text { IL-6, IL-8, IL-15 (87) } \\
\text { Th1: IL-6, IL-8, TNF (67) }\end{array}$ & & $\begin{array}{l}\text { Early pregnancy (86) } \\
\text { Early pregnancy (72) }\end{array}$ & Yes $(71)$ \\
\hline \multicolumn{5}{|l|}{ Respiratory } \\
\hline Syncytial Virus & Th1 (68) & Th2: IL-4 (73) & & Yes (74) \\
\hline \multicolumn{5}{|l|}{ Anaplasma } \\
\hline phagocytophilum & Th1: IFN-gamma (77) & Th2 (76) & & Yes $(75)$ \\
\hline \multicolumn{5}{|l|}{ Listeria } \\
\hline monocytogenes & Th1: IL-12 (79) & & Early pregnancy (80) & Yes $(78)$ \\
\hline \multicolumn{5}{|l|}{ Clostridium } \\
\hline perfringens & Th1: IL-10 (82) & & & Yes $(81)$ \\
\hline Leptospira & $\begin{array}{l}\text { Th1: IL-12, TNF-alpha, } \\
\text { IFN-gamma (85) }\end{array}$ & & & \\
\hline Borna Virus & $\begin{array}{l}\text { In acute infections, Th1: } \\
\text { TNF-alpha, IL-2, IL-6, } \\
\text { IFN-gamma (88) In } \\
\text { chronic, switches to } \\
\text { Th2 (88) }\end{array}$ & & & Yes (84) \\
\hline Cytomegalovirus & & & $\begin{array}{l}\text { Can damage fetus at } \\
\text { any stage in } \\
\text { pregnancy }(55)\end{array}$ & \\
\hline
\end{tabular}

References cited: (1) Thouvenin et al. 1997. (2) Suzuki 1999. (3) Beazley and Egerman 1998. (4) Portugal et al. 2008. (5) Chopra et al. 1997. (6) Zimmer et al. 1996. (7) Sechser et al. 1976. (8) Goluszko and Nowicki 2005. (9) Oliveira et al. 1998. (10) Fernandes et al. 1996. (11) Watarai et al. 2002. (12) Sansonetti et al. 1999. (13) Lafont et al. 2002. (14) Pancorbo et al. 1999. (15) Simor and Ferro 1990. (16) Wooldridge et al. 1996. (17) Gatfield and Pieters 2000. (18) Schlie et al. 2010. (19) Zhang et al. 1995. (20) Sepúlveda et al. 2005. (21) Dodd et al. 2001. (23) Danthi and Chow 2004. (24) Ida-Hosonuma et al. 2005. (25) Varela-Calvino et al. 2002. (26) Triantafilou and Triantafilou 2004. (27) Lindholm et al. 1998. (28) Smythies et al. 2000. (29) Hensley et al. 2011. (30) Murphy et al. 2001. (31) Pucadyil et al. 2004. (32) Hensmann and Kwiatkowski 2001. (33) Fievet et al. 2001. (34) Dumler et al. 2000. (35) Wong et al. 2006. (36) Niemelä et al. 1996. (37) Lauer et al. 2000. (38) Lin and Rikihisa 2003. (39) Lalmanach and Lantier 1999. (40) VanCott et al. 1998. (41) Raupach and Kaufmann 2001. (42) Nawabi et al. 2008. (43) Peltoniemi et al. 2002. (44) Fleeton et al. 1999. (45) Phalen and Kielian 1991. (46) Andersson 1996. (47) Jin et al. 2012. (48) Katzman and Longnecker 2003. (49) Oxenius et al. 1999. (50) Wang et al. 2009b. (51) Chaturvedi et al. 1999. (52) Martínez-Gutierrez et al. 2011. (53) Price et al. 1988. (54) Ornoy and Tenebaum 2006. (55) Morgan-Capner 1991. (56) Hambleton et al. 2007. (57) Wang et al. 2005. (58) Jenkins et al. 1998. (59) Ely et al. 2000. (60) Franssila and Hedman 2004. (61) Avrahami et al. 2008. (62) Dhiman et al. 2010. (63) Conn et al. 1995. (64) Moran et al. 1996. (65) Barman and Nayak 2007. (66) Lieberman et al. 2011. (67) Mistchenko et al. 1994. (68) Martinez-Sobrido et al. 2006. (69) Mercer and Helenius 2009. (70) Grimmer et al. 2002. (71) Imelli et al. 2004. (72) Arechavaleta-Velasco et al. 2008. (73) Hoebee et al. 2003. (74) Gower and Graham 2001. (75) Xiong et al. 2009. (76) Ogden et al. 2002. (77) Pedra et al. 2007. (78) Gekara et al. 2005. (79) Hsieh et al. 1993. (80) Wing and Gregory 2002. (81) Heuck et al. 2010. (82) Karlsson et al. 2002. (83) Khan et al. 2001. (84) Clemente et al. 2009. (85) Kimpel et al. 2003. (86) Lieberman et al. 2011. (87) Hagau et al. 2010. (88) Gluckman and Hanson 2004.

the population level, the picture is more mixed, possibly reflecting both complex relationships between cholesterol levels and immunological robustness and the effects of cholesterol on other aspects of health. Here, we are concerned with the possibility that patterned changes in systemic cholesterol can adaptively mitigate vulnerability to infection entailed by pro- gesterone's effects on the immune system. Given the extent to which pathogens are dependent on cholesterol, if humans have indeed evolved mechanisms capable of such compensatory adjustment, then we should expect to find evidence of an evolutionary arms race between human hosts and a variety of pathogens, as each seeks to gain control of cholesterol availability in 
order to determine the outcome of infection.

\section{ARMS RACES BETWEEN HOST AND PATHOGENS OVER CHOLESTEROL REGULATION/SYNTHESIS}

There appears to be a correlation between innate immune signaling processes and the regulation of sterol metabolism (Castrillo et al. 2003; Ogawa et al. 2005; Zelcer and Tontonoz 2006; Wang et al. 2009a). In keeping with the role of cholesterol in infection and the corresponding strategic value of its regulation, a relationship has been demonstrated between the cholesterol-metabolic pathway and protection against, or susceptibility to, infection (Blanc et al. 2011). Specifically, mammalian hosts produce high levels of interferons after infection with a range of viruses; in turn, via interferon receptors, high levels of interferons lower enzyme levels on the cholesterol pathway, resulting in a net reduction in cholesterol availability (Blanc et al. 2011). Host reduction of cholesterol as a defense mechanism is also observed in conjunction with the hepatitis $\mathrm{C}$ virus (HCV) (Walters et al. 2006). However, in keeping with the advantages to the pathogen of cholesterol abundance, HCV counters this move by impairing lipid metabolism and causing an unregulated increase in cholesterol and fatty acid synthesis (Nakamuta et al. 2009). In response, infected cells catalyze rate-limiting steps in the cholesterol pathway to reduce the amount of cholesterol produced, while increased expression of genes associated with peroxisomes, which are capable of breaking down cholesterol, suggests attempts to prevent the pathogen from utilizing previously produced cholesterol (Walters et al. 2006). Thus, it appears that the host is engaged in an arms race with HCV to regulate the production and availability of cholesterol. The same is likely true of other pathogens as well as, in a variety of viral pathogens, there is a correlation between increased virulence and increase in fatty acid supply and synthesis. Human cytomegalovirus has been shown to alter fatty acid biosynthesis pathways to increase fatty acid supply, which is essential for optimal viral growth (Munger et al. 2008). West Nile virus acts similarly, modulating host cell cholesterol homeostasis by upregulating cholesterol biosynthesis and redistributing cholesterol to viral replication membranes (Mackenzie et al. 2007); the same pattern has been shown in both Dengue virus (Heaton et al. 2010) and HIV (Taylor et al. 2011). It is thus quite likely that natural selection has favored host mechanisms that reduce or sequester cholesterol as a means of combating pathogens.

THE CONJUNCTION OF

PROGESTERONE-DRIVEN RISK OF INFECTION

AND CHOLESTEROL DEPENDENCE IN PATHOGENS

In order to test our hypothesis that progesterone's effects on cholesterol constitute a second-order adaptation that reduces the costs of progesterone's immunomodulatory effects, we turn to an examination of the postulated selection pressures at issue. Specifically, if cholesterol reduction is a preemptive defensive maneuver aimed at decreasing the threat posed by those pathogens that stand to benefit from progesterone's immunomodulatory effects-most notably including those pathogens that pose a substantial risk to mother and conceptus-then it should be the case that a majority of such pathogens are importantly dependent on host cholesterol for their success. We therefore conducted an extensive literature search to identify such pathogens, then explored the extent to which they are known to be dependent on cholesterol. Table 1 presents our findings.

As evident in Table 1 and illustrated in Figure 1, a wide range of pathogens utilize cholesterol for maximal infectivity. As illustrated in Figure 2, almost all of these are best countered by a Th1 cytokine response in the host and, as illustrated in Figure 3, a large number are exacerbated by a Th2 cytokine response. Progesterone shifts the Th1/Th2 balance toward the latter; therefore, it follows that progesterone increases the susceptibility of the host to the pathogens listed. As evident in Figure 4, many of these pathogens also pose a substantial risk during early pregnancy, a period charac- 


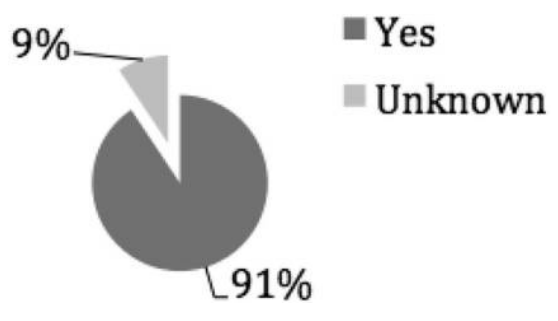

Figure 1. Fraction of Pathogens Examined that Utilize Cholesterol $(\mathrm{N}=32)$.

terized by a "perfect storm" of minimal immunological capacities and maximal susceptibility to perturbation. Progesterone's general reduction of cholesterol, and the first-trimester nadir in maternal cholesterol in particular, thus appears to reflect a beneficial adaptation that helps protect both mother and conceptus from pathogenic infection.

\section{Cholesterol During Pregnancy}

Despite progressive increases in progesterone levels, cholesterol levels increase during gestation; plasma concentration increases about $50 \%$ on average, the major increase occurring during the second trimester (Potter and Nestel 1979; Basaran 2009), while plasma triglyceride concentration reaches a peak in the third trimester (Potter and Nestel 1979; Basaran 2009). In regard to both LDLs and HDLs, the ratio of triglycerides to cholesterol rises throughout the course of pregnancy (Potter and Nestel 1979). At the proximate level, the increase in maternal cholesterol is likely due to the effects of estrogens, which elevate cholesterol significantly (Schaefer et al. 1983).

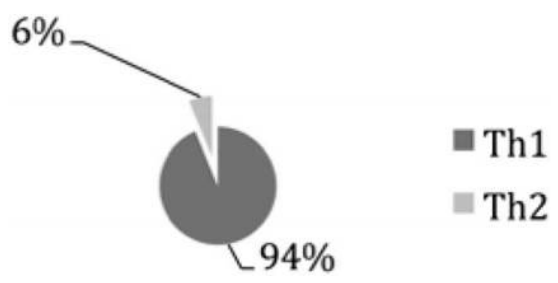

Figure 2. PATHOGENS FOR Which the INFECTION Cycle is Maximally Limited by Thl or Th2 Responses $(\mathrm{N}=32)$.

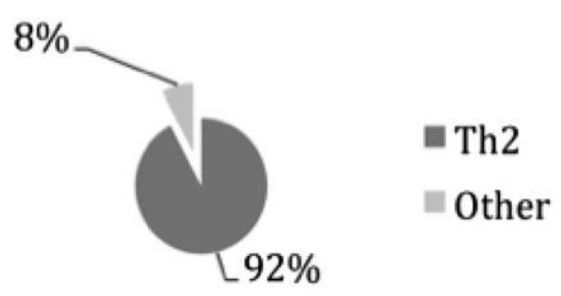

Figure 3. Pathogens for which the Infection Cycle is Maximally Enhanced by Thl or Th2 Responses $(\mathrm{N}=13)$.

Estrogen increases progressively throughout pregnancy (Hassiakos et al. 1991). Levels of LDL parallel this rise, and the same is true of HDL through mid-pregnancy (maternal HDL levels fall late in pregnancy, possibly due to the onset of insulin resistance, glucose intolerance, and enhanced fatty acid mobilization; Ordovas et al. 1984). At the ultimate level, these increases can be correlated to the increased need for cholesterol by the fetus. Fetal cholesterol is very high at the end of the second trimester, a period vital to the neural and vascular growth of the developing organism (Herrera and Amusquivar 2000). Cholesterol accessibility in the second and third trimesters helps enhance basic fetal metabolism and function via normalized membrane integrity and cell signaling (Woollett 2005). Cholesterol is used by the placenta for steroid synthesis and fatty acids are used for placental oxidation and membrane formation (Mankuta et al. 2010). The third trimester is also marked by body fat accretion in the fetus, a process fundamentally dependent on maternal cholesterol (Herrera and Amusquivar 2000).

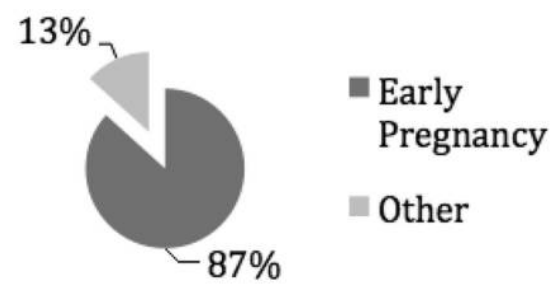

Figure 4. Period of Maximal Negative Impact of Infection Among Pathogens Known to Affect the Course of Pregnancy $(\mathrm{N}=15)$. 
Importantly, as pregnancy progresses, the fetus becomes increasingly buffered from infection, and fetal development becomes increasingly less vulnerable to perturbation (reviewed in Profet 1992). Meanwhile, the fetal demand for cholesterol continues to climb throughout development, with the fetus matching any increase in maternal cholesterol intake with corresponding elevations in fetal cholesterol uptake (Burke et al. 2009). As reflected by the correlation between elevated maternal cholesterol and increased fetal growth rates (McConihay et al. 2000), just as vulnerability to infection and susceptibility to perturbation decline over the second and third trimesters, so too does the fetal need for cholesterol increase. Against this backdrop, the steady increase in cholesterol across the second and third trimesters is understandable as an adaptive pattern, reflecting a reduction in the immunological costs of cholesterol and an increase in the need for this vital building block.

\section{Conclusion}

Cholesterol modulation appears to be exquisitely timed over the course of pregnancy, closely matching the shifting importance of combating pathogens and building fetal tissue. The functionality of these changes is evident in the closeness of fit between the ability of pathogens to exploit progesteroneinduced downregulation of inflammatory responses and their reliance on cholesterol. Taken together, these features indicate that the relationship between progesterone and cholesterol, although puzzling at first glance, most likely reflects a second-order adaptation selected for by the increased vulnerability to infection that is an inherent consequence of progesterone's role in maternal immune tolerance of the conceptus. Indeed, it is possible that this is but one in a suite of secondorder adaptations serving this purpose. Progesterone may exercise a similar antag- onistic effect on the availability of iron (see Fessler 2002), and there is evidence that estrogen has an antagonistic effect on the availability of tryptophan (Doyle et al. 2007). Like cholesterol, iron and tryptophan play critical roles in infection, suggesting the presence of evolved systems that compensate for the liabilities entailed by reproductive immunomodulation (Fessler 2002; Doyle et al. 2007).

The approach presented here has a number of possible implications for both clinical practice and basic research. First, if we are correct that cholesterol-dependent pathogens pose a substantial risk to the conceptus then, via pathways different from those recognized to date in the literature (e.g., Bartels and O'Donoghue 2011), chronically high cholesterol levels may constitute an underrecognized factor in both pregnancy loss and a variety of developmental abnormalities. Second, if, as seems plausible, multiple feedback mechanisms link progesterone production to cholesterol, then pharmacological manipulation of cholesterol levels may entail unintended consequences for progesterone production, with subsequent effects on fertility and other aspects of health. Third, in light of existing evidence that progesterone shapes behavioral disease avoidance in a manner that partially compensates for the immunomodulation effects of this hormone, if the thesis presented here is correct, this would constitute a case of two entirely independent compensatory mechanisms linked to a single proximate system. The latter suggests that evolutionary investigations of health and disease should attend carefully to the possibility of complex, and even multiple, second-order adaptations stemming from constraints on the optimality of individual adaptations.

\section{ACKNOWLEDGMENTS}

We thank two anonymous reviewers for helpful feedback.

\section{REFERENCES}

Ahumada Hemer H., Valles de Bourges V., Juarez Ayala J., Brito G., Díaz-Sánchez V., Garza-Flores J. 1985. Variations in serum lipids and lipoproteins throughout the menstrual cycle. Fertility and Sterility 44:80-84.

Akahoshi M., Soda M., Nakashima E., Shimaoka K., 
Seto S., Yano K. 1996. Effects of menopause on trends of serum cholesterol, blood pressure, and body mass index. Circulation 94:61-66.

Almog Y. 2003. Statins, inflammation, and sepsis: hypothesis. CHEST 124:740-743.

Alvarez C., Ramos A. 1986. Lipids, lipoproteins, and apoproteins in serum during infection. Clinical Chemistry 32:142-145.

Andersson J. 1996. Clinical and immunological considerations in Epstein-Barr virus-associated diseases. Scandinavian Journal of Infectious Diseases 100: $72-82$.

Arechavaleta-Velasco F., Gomez L., Ma Y., Zhao J., McGrath C. M., Sammel M. D., Nelson D. B., Parry S. 2008. Adverse reproductive outcomes in urban women with adeno-associated virus-2 infections in early pregnancy. Human Reproduction 23:29-36.

Arnold L. E. 1990. Childhood Stress. New York: John Wiley and Sons.

Assmann G., Gotto A. M. Jr. 2004. HDL cholesterol and protective factors in atherosclerosis. Circulation 109:III-8-III-14.

Avrahami D., Dayan-Amouyal Y., Tal S., Mincberg M., Davis C., Abramsky O., Gabizon R. 2008. Virusinduced alterations of membrane lipids affect the incorporation of $\mathrm{PrP}^{\mathrm{Sc}}$ into cells. Journal of Neuroscience Research 86:2753-2762.

Barman S., Nayak D. P. 2007. Lipid raft disruption by cholesterol depletion enhances influenza A virus budding from MDCK cells. Journal of Virology 81: 12169-12178.

Bartels Ä., O’Donoghue K. 2011. Cholesterol in pregnancy: a review of knowns and unknowns. Obstetric Medicine 4:147-151.

Basaran A. 2009. Pregnancy-induced hyperlipoproteinemia: review of the literature. Reproductive Sciences 16:431-437.

Beazley D. M., Egerman R. S. 1998. Toxoplasmosis. Seminars in Perinatology 22:332-338.

Blanc M., Hsieh W. Y., Robertson K. A., Watterson S., Shui G., Lacaze P., Khondoker M., Dickinson P., Sing G., Rodríguez-Martín S., Phelan P., Forster T., Strobl B., Müller M., Riemersma R., Osborne T., Wenk M. R., Angulo A., Ghazal P. 2011. Host defense against viral infection involves interferon mediated down-regulation of sterol biosynthesis. PLoS Biology 9:e1000598.

Brizzi P., Tonolo G., Esposito F., Puddu L., Dessole S., Maioli M., Milia S. 1999. Lipoprotein metabolism during normal pregnancy. American Journal of $\mathrm{Ob}$ stetrics and Gynecology 181:430-434.

Burke K. T., Colvin P. L., Myatt L., Graf G. A., Schroeder F., Woollett L. A. 2009. Transport of maternal cholesterol to the fetus is affected by maternal plasma cholesterol concentrations in the Golden Syrian hamster. Journal of Lipid Research 50:11461155 .
Butte N. F. 2000. Carbohydrate and lipid metabolism in pregnancy: normal compared with gestational diabetes mellitus. American Journal of Clinical Nutrition 71:1256-1261.

Canturk N. Z., Canturk Z., Okay E., Yirmibesoglu O., Eraldemir B. 2002. Risk of nosocomial infections and effects of total cholesterol, HDL cholesterol in surgical patients. Clinical Nutrition 21:431-436.

Castrillo A., Joseph S. B., Vaidya S. A., Haberland M., Fogelman A. M., Cheng G., Tontonoz P. 2003. Crosstalk between LXR and toll-like receptor signaling mediates bacterial and viral antagonism of cholesterol metabolism. Molecular Cell 12:805-816.

Catron D. M., Lange Y., Borensztajn J., Sylvester M. D., Jones B. D., Haldar K. 2004. Salmonella enterica serovar typhimurium requires nonsterol precursors of the cholesterol biosynthetic pathway for intracellular proliferation. Infection and Immunity 72:1036-1042.

Chaturvedi U. C., Elbishbishi E. A., Agarwal R., Raghupathy R., Nagar R., Tandon R., Pacsa A. S., Younis O. I., Azizieh F. 1999. Sequential production of cytokines by dengue virus-infected human peripheral blood leukocyte cultures. Journal of Medical Virology 59:335-340.

Chazal N., Gerlier D. 2003. Virus entry, assembly, budding, and membrane rafts. Microbiology and Molecular Biology Reviews 67:226-237.

Chong K. T., Mims C. A. 1984. Effects of pregnant mouse serum and pregnancy hormones on the replication in vitro of murine cytomegalovirus. Archives of Virology 82:223-231.

Chopra U., Vohra H., Chhibber S., Ganguly N. K., Sharma S. 1997. $\mathrm{Th}_{1}$ pattern of cytokine secretion by splenic cells from pyelonephritic mice after in-vitro stimulation with hsp-65 of Escherichia coli. Journal of Medical Microbiology 46:139-144.

Clemente R., de Parseval A., Perez M., de la Torre J. C. 2009. Borna disease virus requires cholesterol in both cellular membrane and viral envelope for efficient cell entry. Journal of Virology 83:26552662.

Conn C. A., McClellan J. L., Maassab H. F., Smitka C. W., Majde J. A., Kluger M. J. 1995. Cytokines and the acute phase response to influenza virus in mice. American Journal of Physiology: Regulatory, Integrative and Comparative Physiology 268:R78-R84.

Conway C. A., Jones B. C., DeBruine L. M., Welling L. L. M., Law Smith M. J., Perrett D. I., Sharp M. A., Al-Dujaili E. A. S. 2007. Salience of emotional displays of danger and contagion in faces is enhanced when progesterone levels are raised. Hormones and Behavior 51:202-206.

Danthi P., Chow M. 2004. Cholesterol removal by methyl- $\beta$-cyclodextrin inhibits poliovirus entry. Journal of Virology 78:33-41.

Darmady J., Postle A. 1982. Lipid metabolism in preg- 
nancy. British Journal of Obstetrics and Gynaecology 89:211-215.

Das S., Bhargava S., Manocha A., Kankra M., Ray S., Srivastava L. M. 2011. The prognostic value of hypocholesterolemia in sepsis. Asian Journal of Pharmaceutical and Biological Research 1:41-46.

De León R., Austin K. L., Richards L., Guerrero F. 1992. Lipid and hormonal profile of Panamanian women during the menstrual cycle. International Journal of Gynecology $\mathcal{E}$ Obstetrics 39:219-226.

Delgado-Rodríguez M., Medina-Cuadros M., MartínezGallego G., Sillero-Arenas M. 1997. Total cholesterol, HDL-cholesterol, and risk of nosocomial infection: a prospective study in surgical patients. Infection Control and Hospital Epidemiology 18:9-18.

Delgado-Rodríguez M., Medina-Cuadros M., GómezOrtega A., Martínez-Gallego G., Mariscal-Ortiz M., Martinez-Gonzalez M. A., Sillero-Arenas M. 2002. Cholesterol and serum albumin levels as predictors of cross infection, death, and length of hospital stay. Archives of Surgery 137:805-812.

Dhiman N., Haralambieva I. H., Vierkant R. A., Pankratz V. S., Ryan J. E., Jacobson R. M., Ovsyannikova I. G., Poland G. A. 2010. Predominant inflammatory cytokine secretion pattern in response to two doses of live rubella vaccine in healthy vaccinees. Cytokine 50: 24-29.

Dodd D. A., Giddings T. H. Jr., Kirkegaard K. 2001. Poliovirus 3A protein limits interleukin-6 (IL-6), IL-8, and beta interferon secretion during viral infection. Journal of Virology 75:8158-8165.

Doyle C., Ewald H. A. S., Ewald P. W. 2007. Premenstrual syndrome: an evolutionary perspective on its causes and treatment. Perspectives in Biology and Medicine 50:181-202.

Dumler J. S., Trigiani E. R., Bakken J. S., AgueroRosenfeld M. E., Wormser G. P. 2000. Serum cytokine responses during acute human granulocytic ehrlichiosis. Clinical and Vaccine Immunology 7:6-8.

Eastwick P. W. 2009. Beyond the Pleistocene: using phylogeny and constraint to inform the evolutionary psychology of human mating. Psychological Bulletin 135:794-821.

Edison R. J., Berg K., Remaley A., Kelley R., Rotimi C., Stevenson R. E., Muenke M. 2007. Adverse birth outcome among mothers with low serum cholesterol. Pediatrics 120:723-733.

Ely J. W., Yankowitz J., Bowdler N. C. 2000. Evaluation of pregnant women exposed to respiratory viruses. American Family Physician 61:3065-3072.

Ewald P. W. 2008. An evolutionary perspective on the causes of chronic diseases: atherosclerosis as an illustration. Pages 350-367 in Evolutionary Medicine and Health: New Perspectives, edited by W. R. Trevathan, E. O. Smith, and J. J. McKenna. New York: Oxford University Press.

Faust Z., Laškarin G., Rukavina D., Szekeres-Bartho J.
1999. Progesterone-induced blocking factor inhibits degranulation of natural killer cells. American Journal of Reproductive Immunology 42:71-75.

Feingold K. R., Funk J. L., Moser A. H., Shigenaga J. K., Rapp J. H., Grunfeld C. 1995. Role for circulating lipoproteins in protection from endotoxin toxicity. Infection and Immunity 63:2041-2046.

Fernandes D. M., Jiang X., Jung J. H., Baldwin C. L. 1996. Comparison of $\mathrm{T}$ cell cytokines in resistant and susceptible mice infected with virulent Brucella abortus strain 2308. FEMS Immunology and Medical Microbiology 16:193-203.

Fessler D. M. T. 2001. Luteal phase immunosuppression and meat eating. Rivista di Biologia/Biology Forum 94:403-426.

Fessler D. M. T. 2002. Reproductive immunosuppression and diet: an evolutionary perspective on pregnancy sickness and meat consumption. Current Anthropology 43:19-61.

Fessler D. M. T., Navarrete C. D. 2003. Domainspecific variation in disgust sensitivity across the menstrual cycle. Evolution and Human Behavior 24: 406-417.

Fessler D. M. T., Eng S. J., Navarrete C. D. 2005. Elevated disgust sensitivity in the first trimester of pregnancy: evidence supporting the compensatory prophylaxis hypothesis. Evolution and Human Behavior 26:344-351.

Fievet N., Moussa M., Tami G., Maubert B., Cot M., Deloron P., Chaouat G. 2001. Plasmodium falciparum induces a Th1/Th2 disequilibrium, favoring the Th1-type pathway, in the human placenta. Journal of Infectious Diseases 183:1530-1534.

Fleeton M. N., Sheahan B. J., Gould E. A., Atkins G. J., Liljestrom P. 1999. Recombinant Semliki Forest virus particles encoding the prME or NS1 proteins of louping ill virus protect mice from lethal challenge. Journal of General Virology 80:1189-1198.

Fleischman D. S., Fessler D. M. T. 2011. Progesterone's effects on the psychology of disease avoidance: support for the compensatory behavioral prophylaxis hypothesis. Hormones and Behavior 59: 271-275.

Franssila R., Hedman K. 2004. T-helper cell-mediated interferon- $\gamma$, interleukin-10 and proliferation responses to a candidate recombinant vaccine for human parvovirus B19. Vaccine 22:3809-3815.

Gatfield J., Pieters J. 2000. Essential role for cholesterol in entry of mycobacteria into macrophages. Science 288:1647-1651.

Gekara N. O., Jacobs T., Chakraborty T., Weiss S. 2005. The cholesterol-dependent cytolysis listeriolysin $\mathrm{O}$ aggregates rafts via oligomerization. Cellular Microbiology 7:1345-1356.

Gluckman P. D., Hanson M. A. 2004. Maternal constraint of fetal growth and its consequences. Seminars in Fetal and Neonatal Medicine 9:419-425. 
Goluszko P., Nowicki B. 2005. Membrane cholesterol: a crucial molecule affecting interactions of microbial pathogens with mammalian cells. Infection and Immunity 73:7791-7796.

Gould A. L., Rossouw J. E., Santanello N. C., Heyse J. F., Furberg C. D. 1995. Cholesterol reduction yields clinical benefit: a new look at old data. Circulation 91:2274-2282.

Gower T. L., Graham B. S. 2001. Antiviral activity of lovastatin against respiratory syncytial virus in vivo and in vitro. Antimicrobial Agents and Chemotherapy 45:1231-1237.

Grimmer S., van Deurs B., Sandvig K. 2002. Membrane ruffling and macropinocytosis in A431 cells require cholesterol. Journal of Cell Science 115: 2953-2962.

Grummer R. R., Carroll D. J. 1988. A review of lipoprotein cholesterol metabolism: importance to ovarian function. Journal of Animal Science 66: 3160-3173.

Hagau N., Slavcovici A., Gonganau D. N., Oltean S., Dirzu D. S., Brezoszki E. S., Maxim M., Ciuce C., Mlesnite M., Gavrus R. L., Laslo C., Hagau R., Petrescu M., Studnicska D. M. 2010. Clinical aspects and cytokine response in severe H1N1 influenza A virus infection. Critical Care 14:R203.

Hambleton S., Steinberg S. P., Gershon M. D., Gershon A. A. 2007. Cholesterol dependence of varicella-zoster virion entry into target cells. Journal of Virology 81:7548-7558.

Hassiakos D., Mantzavinos T., Kalomiris K., Zourlas P. A. 1991. Comparison of maternal serum estradiol and progesterone levels in pregnancies after induced and spontaneous ovulation. Archives of Gynecology and Obstetrics 248:145-150.

Hayward R. D., Cain R. J., McGhie E. J., Phillips N., Garner M. J., Koronakis V. 2005. Cholesterol binding by the bacterial type III translocon is essential for virulence effector delivery into mammalian cells. Molecular Microbiology 56:590-603.

Heaton N. S., Perera R., Berger K. L., Khadka S., LaCount D. J., Kuhn R. J., Randall G. 2010. Dengue virus nonstructural protein 3 redistributes fatty acid synthase to sites of viral replication and increases cellular fatty acid synthesis. Proceedings of the National Academy of Sciences of the United States of America 107:17345-17350.

Hensley L. E., Smith M. A., Geisbert J. B., Fritz E. A., Daddario-DiCaprio K. M., Larsen T., Geisbert T. W. 2011. Pathogenesis of lassa fever in cynomolgus macaques. Virology Journal 8:205.

Hensmann M., Kwiatkowski D. 2001. Cellular basis of early cytokine response to Plasmodium falciparum. Infection and Immunity 69:2364-2371.

Herrera E., Amusquivar E. 2000. Lipid metabolism in the fetus and the newborn. Diabetes/Metabolism Research and Reviews 16:202-210.
Heuck A. P., Moe P. C., Johnson B. B. 2010. The cholesterol-dependent cytolysin family of grampositive bacterial toxins. Subcellular Biochemistry 51: $551-577$.

Hoebee B., Rietveld E., Bont L., van Oosten M., Hodemaekers H. M., Nagelkerke N. J. D., Neijens H. J., Kimpen J. L. L., Kimman T. G. 2003. Association of severe respiratory syncytial virus bronchiolitis with interleukin- 4 and interleukin- 4 receptor $\alpha$ polymorphisms. Journal of Infectious Diseases 187:2-11.

Holt P. G., Jones C. A. 2000. The development of the immune system during pregnancy and early life. Allergy 55:688-697.

Hsieh C. S., Macatonia S. E., Tripp C. S., Wolf S. F., O'Garra A., Murphy K. M. 1993. Development of Th1 CD4+ T cells through IL-12 produced by Listeria-induced macrophages. Science 260:547549.

Ida-Hosonuma M., Iwasaki T., Yoshikawa T., Nagata N., Sato Y., Sata T., Yoneyama M., Fujita T., Taya C., Yonekawa H., Koike S. 2005. The alpha/beta interferon response controls tissue tropism and pathogenicity of poliovirus. Journal of Virology 79: 4460-4469.

Imelli N., Meier O., Boucke K., Hemmi S., Greber U. F. 2004. Cholesterol is required for endocytosis and endosomal escape of adenovirus type 2. Journal of Virology 78:3089-3098.

Innis S. M. 2005. Essential fatty acid transfer and fetal development. Placenta 26:S70-S75.

Iribarren C., Jacobs D. R., Sidney S., Claxton A. J., Feingold K. R. 1998. Cohort study of serum total cholesterol and in-hospital incidence of infectious diseases. Epidemiology and Infection 121:335-347.

Jenkins D. E., Redman R. L., Lam E. M., Liu C., Lin I., Arvin A. M. 1998. Interleukin (IL)-10, IL-12, and interferon- $\gamma$ production in primary and memory immune responses to varicella-zoster virus. Journal of Infectious Diseases 178:940-948.

Jerwood S., Cohen J. 2008. Unexpected antimicrobial effect of statins. Journal of Antimicrobial Chemotherapy 61:362-364.

Jin C. Q., Liu F., Dong H.-X., Zhang J., Zhou J.-W., Song L., Xiao H., Zheng B.-Y. 2012. Type 2 polarized immune response holds a major position in Epstein-Barr virus-related idiopathic thrombocytopenic purpura (EBV-ITP). International Journal of Laboratory Hematology 34:164-171.

Jones B. C., Perrett D. I., Little A. C., Boothroyd L., Cornwell R. E., Feinberg D. R., Tiddeman B. P., Whiten S., Pitman R. M., Hillier S. G., Burt D. M., Stirrat M. R., Law Smith M. J., Moore F. R. 2005. Menstrual cycle, pregnancy and oral contraceptive use alter attraction to apparent health in faces. Proceedings of the Royal Society B: Biological Sciences 272:347-354.

Jones D. Y., Judd J. T., Taylor P. R., Campbell W. S., 
Nair P. P. 1988. Menstrual cycle effect on plasma lipids. Metabolism 37:1-2.

Karlsson H., Hessle C., Rudin A. 2002. Innate immune responses of human neonatal cells to bacteria from the normal gastrointestinal flora. Infection and Immunity 70:6688-6696.

Katzman R. B., Longnecker R. 2003. Cholesteroldependent infection of Burkitt's lymphoma cell lines by Epstein-Barr virus. Journal of General Virology 84:2987-2992.

Kenis I., Tartakover-Matalon S., Cherepnin N., Drucker L., Fishman A., Pomeranz M., Lishner M. 2005. Simvastatin has deleterious effects on human first trimester placental explants. Human Reproduction 20:2866-2872.

Khan M. Y., Mah M. W., Memish Z. A. 2001. Brucellosis in pregnant women. Clinical Infectious Diseases 32:1172-1177.

Kim H.-J., Kalkhoff R. K. 1979. Changes in lipoprotein composition during the menstrual cycle. Metabolism 28:663-668.

Kimpel G. R., Matthias M. A., Vinetz J. M. 2003. Leptospira interrogans activation of human peripheral blood mononuclear cells: preferential expansion of TCR $\gamma \delta^{+} \mathrm{T}$ cells vs. TCR $\alpha \beta^{+} \mathrm{T}$ cells. Journal of Immunology 171:1447-1455.

Kolejáková K., Petrovič R., Turčáni P., Böhmer D., Chandoga J. 2010. The role of cholesterol in embryogenesis and the Smith-Lemli-Opitzov syndrome. Československá fysiologie 59:37-43.

Kovanen P. T., Nikkilä E. A., Miettinen T. A. 1975. Regulation of cholesterol synthesis and storage in fat cells. Journal of Lipid Research 16:211-223.

Kronmal R. A., Cain K. C., Ye Z., Omenn G. S. 1993. Total serum cholesterol levels and mortality risk as a function of age: a report based on the Framingham data. Archives of Internal Medicine 153:10651073.

Krumholz H. M., Seeman T. E., Merrill S. S., Mendes de Leon C. F., Vaccarino V., Silverman D. I., Tsukahara R., Ostfeld A. M., Berkman L. F. 1994. Lack of association between cholesterol and coronary heart disease mortality and morbidity and allcause mortality in persons older than 70 years. JAMA: Journal of the American Medical Association 272:1335-1340.

Lafont F., Tran Van Nhieu G., Hanada K., Sansonetti P., van der Goot F. G. 2002. Initial steps of Shigella infection depend on the cholesterol/sphingolipid raft-mediated CD44-IpaB interaction. EMBO Journal 21:4449-4457.

Lalmanach A.-C., Lantier F. 1999. Host cytokine response and resistance to Salmonella infection. Microbes and Infection 1:719-726.

Lamon-Fava S., Postfai B., Diffenderfer M., DeLuca C., O'Connor J. Jr., Welty F. K., Dolnikowski G. G., Barrett P. H. R., Schaefer E. J. 2006. Role of the estrogen and progestin in hormonal replacement therapy on apolipoprotein A-I kinetics in postmenopausal women. Arteriosclerosis, Thrombosis, and Vascular Biology 26:385-391.

Lange Y. 1994. Cholesterol movement from plasma membrane to rough endoplasmic reticulum. Inhibition by progesterone. Journal of Biological Chemistry 269:3411-3414.

Lauer S., VanWye J., Harrison T., McManus H., Samuel B. U., Hiller N. L., Mohandas N., Haldar K. 2000. Vacuolar uptake of host components, and a role for cholesterol and sphingomyelin in malarial infection. EMBO Journal 19:3556-3564.

Lecerf J.-M., de Lorgeril M. 2011. Dietary cholesterol: from physiology to cardiovascular risk. British Journal of Nutrition 106:6-14.

Lieberman R. W., Bagdasarian N., Thomas D., Van De Ven C. 2011. Seasonal influenza A (H1N1) infection in early pregnancy and second trimester fetal demise. Emerging Infectious Diseases 17:107-109.

Lin M., Rikihisa Y. 2003. Ehrlichia chaffeensis and Anaplasma phagocytophilum lack genes for lipid A biosynthesis and incorporate cholesterol for their survival. Infection and Immunity 71:5324-5331.

Lindenhall B., Holleran A. L., Aldaghlas T. A., Ruan B., Schroepfer G. J. Jr., Wilson W. K., Kelleher J. K. 2001. Progestins block cholesterol synthesis to produce meiosis-activating sterols. FASEB Journal: Journal of the Federation of American Societies for Experimental Biology 15:775-784.

Lindholm C., Quiding-Järbrink M., Lönroth H., Hamlet A., Svennerholm A.-M. 1998. Local cytokine response in Helicobacter pylori-infected subjects. Infection and Immunity 66:5964-5971.

Liu C.-I., Liu G. Y., Song Y., Yin F., Hensler M. E., Jeng W.-Y., Nizet V., Wang A. H.-J., Oldfield E. 2008. A cholesterol biosynthesis inhibitor blocks Staphylococcus aureus virulence. Science 319:1391-1394.

Lockshin M. 2010. Statins for the treatment of obstetric complications in antiphospholipid syndrome? Journal of Reproductive Immunology 84:206-207.

Macdonald R. R. 1989. Does treatment with progesterone prevent miscarriage? BJOG: An International Journal of Obstetrics and Gynaeocology 96:257-260.

Mackenzie J. M., Khromykh A. A., Parton R. G. 2007. Cholesterol manipulation by West Nile virus perturbs the cellular immune response. Cell Host and Microbe 2:229-239.

Maisnier-Patin S., Andersson D. I. 2004. Adaptation to the deleterious effects of antimicrobial drug resistance mutations by compensatory evolution. Research in Microbiology 155:360-369.

Mañes S., del Real G., Martínez A. C. 2003. Pathogens: raft hijackers. Nature Reviews Immunology 3:557568.

Mankuta D., Elami-Suzin M., Elhayani A., Vinker S. 2010. Lipid profile in consecutive pregnancies. Lipids in Health and Disease 9:58. 
Martínez-Gutierrez M., Castellanos J. E., GallegoGómez J. C. 2011. Statins reduce dengue virus production via decreased virion assembly. Intervirology 54:202-216.

Martinez-Sobrido L., Gitiban N., Fernandez-Sesma A., Cros J., Mertz S. E., Jewell N. A., Hammond S., Flano E., Durbin R. K., García-Sastre A., Durbin J. E. 2006. Protection against respiratory syncytial virus by a recombinant Newcastle disease virus vector. Journal of Virology 80:1130-1139.

Matthews K. A., Crawford S. L., Chae C. U., EversonRose S. A., Sowers M. F., Sternfeld B., Sutton-Tyrrell K. 2009. Are changes in cardiovascular disease risk factors in midlife women due to chronological aging or to the menopausal transition? Journal of the American College of Cardiology 54:2366-2373.

Maxfield F. R., Tabas I. 2005. Role of cholesterol and lipid organization in disease. Nature 438:612-621.

McConihay J. A., Honkomp A. M., Granholm N. A., Woollett L. A. 2000. Maternal high density lipoproteins affect fetal mass and extra-embryonic fetal tissue sterol metabolism in the mouse. Journal of Lipid Research 41:424-432.

Medigeshi G. R., Hirsch A. J., Streblow D. N., Nikolich-Zugich J., Nelson J. A. 2008. West Nile virus entry requires cholesterol-rich membrane microdomains and is independent of $\alpha \mathrm{v} \beta 3$ integrin. Journal of Virology 82:5212-5219.

Mercer J., Helenius A. 2009. Virus entry by macropinocytosis. Nature Cell Biology 11:510-520.

Metherall J. E., Waugh K., Li H. 1996. Progesterone inhibits cholesterol biosynthesis in cultured cells: accumulation of cholesterol precursors. Journal of Biological Chemistry 271:2627-2633.

Miner M. D., Chang J. C., Pandey A. K., Sassetti C. M., Sherman D. R. 2009. Role of cholesterol in Mycobacterium tuberculosis infection. Indian Journal of Experimental Biology 47:407-411.

Mistchenko A. S., Diez R. A., Mariani A. L., Robaldo J., Maffey A. F., Bayley-Bustamante G., Grinstein S. 1994. Cytokines in adenoviral disease in children: association of interleukin-6, interleukin- 8 , and tumor necrosis factor alpha levels with clinical outcome. Journal of Pediatrics 124:714-720.

Moran T. M., Isobe H., Fernandez-Sesma A., Schulman J. L. 1996. Interleukin-4 causes delayed virus clearance in influenza virus-infected mice. Journal of Virology 70:5230-5235.

Morgan-Capner P. P. 1991. Viral infections in pregnancy. British Journal of Hospital Medicine 45:150, 154-157.

Munger J., Bennett B. D., Parikh A., Feng X.-J., McArdle J., Rabitz H. A., Shenk T., Rabinowitz J. D. 2008. Systems-level metabolic flux profiling identifies fatty acid synthesis as a target for antiviral therapy. Nature Biotechnology 26:1179-1186.

Murphy M. L., Wille U., Villega E. N., Hunter C. A.,
Farrell J. P. 2001. IL-10 mediates susceptibility to Leishmania donovani infection. European Journal of Immunology 31:2848-2856.

Nakamuta M., Yada R., Fujino T., Yada M., Higuchi N., Tanaka M., Miyazaki M., Kohjima M., Kato M., Yoshimoto T., Harada N., Taketomi A., Maehara Y., Koga M., Nishinakagawa T., Nakashima M., Kotoh K., Enjoji M. 2009. Changes in the expression of cholesterol metabolism-associated genes in HCV-infected liver: a novel target for therapy? International Journal of Molecular Medicine 24:825828.

Navarette C. D., Fessler D. M. T., Eng S. J. 2007. Elevated ethnocentrism in the first trimester of pregnancy. Evolution and Human Behavior 28:60-65.

Nawabi P., Catron D. M., Haldar K. 2008. Esterification of cholesterol by a type III secretion effector during intracellular Salmonella infection. Molecular Microbiology 68:173-185.

Niemelä S., Karttunen T., Korhonen T., Läärä E., Karttunen R., Ikäheimo M., Kesäniemi Y. A. 1996. Could Heliobacter pylori infection increase the risk of coronary heart disease by modifying serum lipid concentrations? Heart 75:573-575.

Ogawa S., Lozach J., Benner C., Pascual G., Tangirala R. K., Westin S., Hoffmann A., Subramaniam S., David M., Rosenfeld M. G., Glass C. K. 2005. Molecular determinants of crosstalk between nuclear receptors and toll-like receptors. Cell 122:707-721.

Ogden N. H., Casey A. N. J., French N. P., Woldehiwet Z. 2002. A review of studies on the transmission of Anaplasma phagocytophilum from sheep: implications for the force of infection in endemic cycles. Experimental and Applied Acarology 28:195-202.

Oliveira S. C., Harms J. S., Rech E. L., Rodarte R. S., Bocca A. L., Goes A. M., Splitter G. A. 1998. The role of $\mathrm{T}$ cell subsets and cytokines in the regulation of intracellular bacterial infection. Brazilian Journal of Medical and Biological Research 31:77-84.

Ono A., Freed E. O. 2005. Role of lipid rafts in virus replication. Advances in Virus Research 64:311-358.

Ordovas J. M., Pocovi M., Grande F. 1984. Plasma lipids and cholesterol esterification rate during pregnancy. Obstetrics and Gynecology 63:20-25.

Ornoy A., Tenebaum A. 2006. Pregnancy outcome following infections by coxsackie, echo, measles, mumps, hepatitis, polio and encephalitis viruses. Reproductive Toxicology 21:446-457.

Oxenius A., Karrer U., Zinkernagel R. M., Hengartner H. 1999. IL-12 is not required for induction of type 1 cytokine responses in viral infections. Journal of Immunology 162:965-973.

Pancorbo P. L., de Pablo M. A., Ortega E., Gallego A. M., Alvarez C., Alvarez de Cienfuegos G. 1999. Evaluation of cytokine production and phagocytic activity in mice infected with Campylobacter jejuni. Current Microbiology 39:129-133. 
Pedra J. H. F., Tao J., Sutterwala F. S., Sukumaran B., Berliner N., Bockenstedt L. K., Flavell R. A., Yin Z., Fikrig E. 2007. IL-12/23p40-dependent clearance of Anaplasma phagocytophilum in the murine model of human anaplasmosis. FEMS Immunology and Medical Microbiology 50:401-410.

Pelkmans L. 2005. Secrets of caveolae- and lipid raftmediated endocytosis revealed by mammalian viruses. Biochimica et Biophysica Acta 1746:295-304.

Peltoniemi J., Setälä N., Broberg E., Röyttä M., Hukkanen V., Salmi A. A., Erälinna J.-P. 2002. Semliki Forest virus infection is enhanced in Th1-prone SJL mice but not in Th2-prone BALB/c mice during Linomide-induced immunomodulation. Journal of Neuroimmunology 132:83-92.

Phalen T., Kielian M. 1991. Cholesterol is required for infection by Semliki Forest virus. Journal of Cell Biology 112:615-623.

Plemenitas A., Havel C. M., Watson J. A. 1990. Sterolmediated regulation of mevalonic acid synthesis: accumulation of 4-carboxysterols as the predominant sterols synthesized in a Chinese hamster ovary cell cholesterol auxotroph (mutant 215). Journal of Biological Chemistry 265:17012-17017.

Pollack P. S., Shields K. E., Burnett D. M., Osborne M. J., Cunningham M. L., Stepanavage M. E. 2005. Pregnancy outcomes after maternal exposure to simvastatin and lovastatin. Birth Defects Research Part A: Clinical and Molecular Teratology 73:888-896.

Portugal L. R., Fernandes L. R., Pietra Pedroso V. S., Santiago H. C., Gazzinelli R. T., Alvarez-Leite J. I. 2008. Influence of low-density lipoprotein (LDL) receptor on lipid composition, inflammation and parasitism during Toxoplasma gondii infection. Microbes and Infection 10:276-284.

Potter J.-M., Nestel P. J. 1979. The hyperlipidemia of pregnancy in normal and complicated pregnancies. American Journal of Obstetrics and Gynecology 133:165-170.

Price M. E., Fisher-Hoch S. P., Craven R. B., McCormick J. B. 1988. A prospective study of maternal and fetal outcome in acute lassa fever infection during pregnancy. British Medical Journal 297:584-587.

Profet M. 1992. Pregnancy sickness as adaptation: a deterrent to maternal ingestion of teratogens. Pages 327-365 in The Adapted Mind: Evolutionary Psychology and the Generation of Culture, edited by L. C. J. Barkow, L. Cosmides, and J. Tooby. New York: Oxford University Press.

Pucadyil T. J., Tewary P., Madhubala R., Chattopadhyay A. 2004. Cholesterol is required for Leishmania donovani infection: implications in leishmaniasis. Molecular and Biochemical Parasitology 133:145-152.

Raupach B., Kaufmann S. H. E. 2001. Bacterial virulence, proinflammatory cytokines and host immunity: how to choose the appropriate Salmonella vaccine strain? Microbes and Infection 3:1261-1269.
Ravnskov U. 2003. High cholesterol may protect against infections and atherosclerosis. Quarterly Journal of Medicine 96:927-934.

Razzolini R., Tarantini G., Ossena G., Favaretto E., Bilato C., Manzato E., Dalla-Volta S., Iliceto S. 2008. Non-cardiovascular mortality, low-density lipoprotein cholesterol and statins: a meta-regression analysis. Cardiology 109:110-116.

Rosenberger C. M., Brumell J. H., Finlay B. B. 2000. Microbial pathogenesis: lipid rafts as pathogen portals. Current Biology 10:R823-R825.

Saher G., Quintes S., Nave K.-A. 2011. Cholesterol: a novel regulatory role in myelin formation. Neuroscientist 17:79-93.

Salen G., Shefer S., Batta A. K., Tint G. S., Xu G., Honda A., Irons M., Elias E. R. 1996. Abnormal cholesterol biosynthesis in the Smith-Lemli-Opitz syndrome. Journal of Lipid Research 37:1169-1180.

Sansonetti P. J., Arondel J., Huerre M., Harada A., Matsushima K. 1999. Interleukin-8 controls bacterial transepithelial translocation at the cost of epithelial destruction in experimental shigellosis. Infection and Immunity 67:1471-1480.

Schaefer E. J., Foster D. M., Zech L. A., Lindgren F. T., Brewer H. B. Jr., Levy R. I. 1983. The effects of estrogen administration on plasma lipoprotein metabolism in premenopausal females. Journal of Clinical Endocrinology and Metabolism 57:262-267.

Schlie K., Maisa A., Lennartz F., Ströher U., Garten W., Strecker T. 2010. Characterization of lassa virus glycoprotein oligomerization and influence of cholesterol on virus replication. Journal of Virology 84:983-992.

Sechser T., Vaněcek J., Rasková H., Jiricka Z., Matějovská D., Matějovská V. 1976. Pregnancy interrupting effects of some bacterial toxins. Physiologia Bohemoslovaca 25:155-158.

Sep S., Rijvers C., Smits L., van Bilsen M., Bekers O., Peeters L. 2011. Early-pregnancy changes in maternal lipid profile in women with recurrent preeclampsia and previously preeclamptic women with normal next pregnancy. Reproductive Sciences 18:998-1004.

Sepúlveda R. T., Marchalonis J. J., Watson R. R. 2005. T-cell receptor $\mathrm{V} \beta 8.1$ peptide reduces coxsackievirusinduced cardiopathology in aged mice. Cardiovascular Toxicology 5:21-28.

Shine W. E., Silvany R., McCulley J. P. 1993. Relation of cholesterol-stimulated Staphylococcus aureus growth to chronic blepharitis. Investigative Ophthalmology and Visual Science 34:2291-2296.

Siiteri P. K., Febres F., Clemens L. E., Chang R. J., Gondos B., Stites D. 1977. Progesterone and maintenance of pregnancy: is progesterone nature's immunosuppressant? Annals of the New York Academy of Sciences 286:384-397. 
Simons K., Ikonen E. 2000. How cells handle cholesterol. Science 290:1721-1726.

Simor A. E., Ferro S. 1990. Campylobacter jejuni infection occurring during pregnancy. European Journal of Clinical Microbiology and Infectious Diseases 9:142144.

Smythies L. E., Waites K. B., Lindsey J. R., Harris P. R., Ghiara P., Smith P. D. 2000. Helicobacter pyloriinduced mucosal inflammation is Th1 mediated and exacerbated in IL-4, but not IFN- $\gamma$, genedeficient mice. Journal of Immunology 165:10221029.

Spencer T. E., Bazer F. W. 2002. Biology of progesterone action during pregnancy recognition and maintenance of pregnancy. Frontiers in Bioscience 7:d1879-d1898.

Suzuki Y. 1999. Genes, cells, and cytokines in resistance against development of toxoplasmic encephalitis. Immunobiology 201:255-271.

Szekeres-Bartho J., Csernus V., Hadnagy J., Pacsa A. S. 1983. Immunosuppressive effect of serum progesterone during pregnancy depends on the progesterone binding capacity of the lymphocytes. Journal of Reproductive Immunology 5:81-88.

Szekeres-Bartho J., Faust Z., Varga P. 1995. The expression of a progesterone-induced immunomodulatory protein in pregnancy lymphocytes. American Journal of Reproductive Immunology 34:342348.

Tay P. Y. S., Lenton E. A. 2002. Progesterone profiles in pregnant, non-pregnant, natural and stimulated IVF cycles with and without luteal support. Medical Journal of Malaysia 57:178-187.

Taylor H. E., Linde M. E., Khatua A. K., Popik W., Hildreth J. E. K. 2011. Sterol regulatory elementbinding protein 2 couples HIV-1 transcription to cholesterol homeostasis and t-cell activation. Journal of Virology 85:7699-7709.

Thouvenin M., Candolfi E., Villard O., Klein J. P., Kien T. 1997. Immune response in a murine model of congenital toxoplasmosis: increased susceptibility of pregnant mice and transplacental passage of Toxoplasma gondii are type 2-dependent. Parassitologia 39:279-283.

Tikkanen M. J., Kuusi T., Nikkilä E. A., Stenman U.-H. 1986. Variation of postheparin plasma hepatic lipase by menstrual cycle. Metabolism 35:99-104.

Toescu V., Nuttall S. L., Martin U., Kendal M. J., Dunne F. 2002. Oxidative stress and normal pregnancy. Clinical Endocrinology 57:609-613.

Triantafilou K., Triantafilou M. 2004. Lipid-raftdependent coxsackievirus B4 internalization and rapid targeting to the golgi. Virology 326:6-19.

Tweten R. K. 2005. Cholesterol-dependent cytolysins, a family of versatile pore-forming toxins. Infection and Immunity 73:6199-6209.

VanCott J. L., Chatfield S. N., Roberts M., Hone
D. M., Hohmann E. L., Pascual D. W., Yamamoto M., Kiyono H., McGhee J. R. 1998. Regulation of host immune responses by modification of Salmonella virulence genes. Nature Medicine 4:1247-1252.

Varela-Calvino R., Ellis R., Sgarbi G., Dayan C. M., Peakman M. 2002. Characterization of the T-cell response to coxsackievirus $\mathrm{B} 4$ : evidence that effector memory cells predominate in patients with type 1 diabetes. Diabetes 51:1745-1753.

Walters K.-A., Joyce M. A., Thompson J. C., Smith M. W., Yeh M. M., Proll S., Zhu L.-F., Gao T. J., Kneteman N. M., Tyrrell D. L., Katze M. G. 2006. Host-specific response to $\mathrm{HCV}$ infection in the chimeric SCID-beige/Alb-uPA mouse model: role of the innate antiviral immune response. PLoS Pathogens 2:e59.

Wang J. P., Kurt-Jones E. A., Shin O. S., Manchak M. D., Levin M. J., Finberg R. W. 2005. Varicellazoster virus activates inflammatory cytokines in human monocytes and macrophages via toll-like receptor 2. Journal of Virology 79:12658-12666.

Wang S., Wu D., Lamon-Fava S., Matthan N. R., Honda K. L., Lichtenstein A. H. 2009a. In vitro fatty acid enrichment of macrophages alters inflammatory response and net cholesterol accumulation. British Journal of Nutrition 102:497-501.

Wang W., Fu Y. J., Zu Y. G., Wu N., Reichling J., Efferth T. 2009b. Lipid rafts play an important role in the vesicular stomatitis virus life cycle. $A r$ chives of Virology 154:595-600.

Watarai M., Makino S., Fujii Y., Okamoto K., Shirahata T. 2002. Modulation of Brucella-induced macropinocytosis by lipid rafts mediates intracellular replication. Cellular Microbiology 4:341-355.

Weverling-Rijnsburger A. W. E., Blauw G. J., Lagaay A. M., Knock D. L., Meinders A. E., Westendorp R. G. J. 1997. Total cholesterol and risk of mortality in the oldest old. Lancet 350:1119-1123.

Wing E. J., Gregory S. H. 2002. Listeria monocytogenes: clinical and experimental update. Journal of Infectious Diseases 185:S18-S24.

Wong J., Zhang J., Gao G., Esfandiarei M., Si X., Wang Y., Yanagawa B., Suarez A., McManus B., Luo H. 2006. Liposome-mediated transient transfection reduces cholesterol-dependent coxsackievirus infectivity. Journal of Virological Methods 133:211-218.

Wooldridge K. G., Williams P. H., Ketley J. M. 1996. Host signal transduction and endocytosis of $\mathrm{Cam}$ pylobacter jejuni. Microbial Pathogenesis 21:299-305.

Woollett L. A. 2005. Maternal cholesterol in fetal development: transport of cholesterol from the maternal to the fetal circulation. American Journal of Clinical Nutrition 82:1155-1161.

Woollett L. A. 2011. Review: transport of maternal cholesterol to the fetal circulation. Placenta 32: S218-S221.

Wright H. T. Jr. 1966. Congenital anomalies and viral in- 
fections in infants-the etiologic role of maternal viral infections. Western Journal of Medicine 105:345-351.

Wu Z., Wu X., Zhang Y. 1990. Relationship of menopausal status and sex hormones to serum lipids and blood pressure. International Journal of Epidemiology 19:297-302.

Wynn V., Niththyananthan R. 1982. The effect of progestins in combined oral contraceptives on serum lipids with special reference to high-density lipoproteins. American Journal of Obstetrics and Gynecology 142:766-771.

Xiong Q., Lin M., Rikihisa Y. 2009. Cholesteroldependent Anaplasma phagocytophilum exploits the low-density lipoprotein uptake pathway. PLoS Pathogens 5:e1000329.

Yeagle P. L. 1985. Cholesterol and the cell membrane. Biochimica et Biophysics Acta 822:267-287.

Yoshida S., Wada Y. 2005. Transfer of maternal cholesterol to embryo and fetus in pregnant mice. Journal of Lipid Research 46:2168-2174.
Zelcer N., Tontonoz P. 2006. Liver X receptors as integrators of metabolic and inflammatory signaling. Journal of Clinical Investigation 116:607-614.

Zhang M., Lin Y., Iyer D. V., Gong J., Abrams J. S., Barnes P. F. 1995. T-cell cytokine responses in human infection with Mycobacterium tuberculosis. Infection and Immunity 63:3231-3234.

Zhang Y., Zanotti I., Reilly M. P., Glick J. M., Rothblat G. H., Rader D. J. 2003. Overexpression of apolipoprotein A-I promotes reverse transport of cholesterol from macrophages to feces in vivo. Circulation 108:661-663.

Zimmer S., Pollard V., Marshall G. D., Garofalo R. P., Traber D., Prough D., Herndon D. N. 1996. The 1996 Moyer Award: effects of endotoxin on the Th1/Th2 response in humans. Journal of Burn Care and Rehabilitation 17:491-496.

Associate Editor: Paul W. Ewald 